\title{
Augmentation of Cellular Immunity by Kigamicin D
}

\author{
Toru Masuda, Shunichi Ohba, Manabu Kawada, Masatomi Iijima, Hiroyuki Inoue, \\ Michiyo Osono, Daishiro Ikeda, Setsuko Kunimoto
}

Received: December 16, 2005 / Accepted: March 29, 2006

(C) Japan Antibiotics Research Association

\begin{abstract}
Kigamicin D did not show any immunosuppressive activity in mixed lymphocyte culture reaction and mitogen induced lymphocyte blastogenesis in vitro and graft versus host reaction in vivo. Natural killer cell activity in spleen cells was not affected by oral administration of kigamicin D. Instead, delayed-type hypersensitivity response to sheep red blood cells was stimulated at a broad dosage level. It is concluded that kigamicin D increases cellular immunity to specific antigen.
\end{abstract}

Keywords kigamicin D, cellular immunity, delayed-type hypersensitivity

\section{Introduction}

Kigamicin D is a novel anticancer agent based on a new strategy targeting cancer cells' tolerance to nutrient starvation [1,2]. Oral administration of kigamicin D showed strong antitumor effect on human pancreatic tumor xenografts such as PANC-1, Capan-1, and MIA Paca-2 on nude or scid mice [2]. But it did not show good activity on the other xenograft and syngeneic tumor models tested [3]. On the contrary it augmented the tumor growth of IMC carcinoma, which is a sensitive tumor to immunomodulator such as bestatin [3]. The relationship between dosage and tumor growth of IMC carcinoma was an inverted bellshaped curve as previously decribed [4]. We doubted immunosuppressive activity of kigamicin D and tested its effect on immune response such as mixed lymphocyte

T. Masuda (Corresponding author), S. Ohba, M. Kawada, M. Iijima, H. Inoue, M. Osono, D. Ikeda, S. Kunimoto: Numazu Bio-Medical Research Institute, Microbial Chemistry Research Center, 18-24 Miyamoto, Numazu-shi, Shizuoka 410-0301, Japan, E-mail: masudat@bikaken.or.jp culture reaction (MLCR), graft versus host reaction (GvHR), natural killer (NK) cells activity, and delayed-type hypersensitivity (DTH). As will be described below, kigamicin D showed no sign of immunosuppressive activity, but markedly augmented cellular immunity.

\section{Materials and Methods}

\section{Kigamicin D and Other Chemicals}

Kigamicin D was prepared by us by the method previously described [4]. For in vivo experiments Kigamicin D was dissolved as the highest concentration administered in saline solution supplemented with $10 \%$ DMSO, $0.5 \%$ Tween 80 and stored in a refrigerator for a week. Before administration, the stock solution was diluted with saline to give needed concentration in $0.25 \mathrm{ml}$. Mitomycin C, Concanavalin A (Con A), lipopolysaccharide (LPS, Escherichia coli 0127), and $\left[6-{ }^{3} \mathrm{H}\right]$-thymidine $(814 \mathrm{Gbq} / \mathrm{mmol})$ were purchased from Kyowa Hakko Kogyo Co. Ltd., Tokyo, Japan, Pharmacia AB, Stockholm, Sweden, Difco Laboratories, Michigan, USA, and Amersham Biosciences, UK, respectively.

\section{Preparation of Spleen Cells}

Mice spleens were removed aseptically and single cells suspension were obtained by dispersing the spleens using a syringe and pressing through stainless steel mesh. Erythrocytes were lysed by a 10-s exposure to ice cold distilled water. Spleen cells were washed with RPMI1640 and resuspended in RPMI1640 containing 10\% FBS. Cells were counted in a hemacytometer.

\section{Mixed Lymphocyte Culture Reaction (MLCR)}

MLCR was performed according to the commonly used method described previously [5]. Briefly, spleen cells 
$\left(2 \times 10^{5}\right)$ taken from $\mathrm{C}_{3} \mathrm{H} / \mathrm{He}$ mice $\left(8 \sim 12\right.$ weeks old, $\left.\mathrm{H}-2^{\mathrm{k}}\right)$ and passed through a nylon wool column were used as a responder. As stimulator cells, spleen cells $\left(2 \times 10^{5}\right)$ were taken from BALB/c mice $\left(8 \sim 12\right.$ weeks old, $\left.\mathrm{H}-2^{\mathrm{d}}\right)$ and treated with mitomycin $\mathrm{C}$ at $37^{\circ} \mathrm{C}$ for 20 minutes. Responder cells and stimulator cells were mixed and cultured for 72 hours with kigamicin D, Con A and/or LPS. Kigamicin D was dissolved in DMSO $(10 \mathrm{mg} / \mathrm{ml})$ as a stock solution and diluted with PBS just before use. The culture was pulsed with $0.5 \mu \mathrm{Ci}$ per well of ${ }^{3} \mathrm{H}$-thymidine 16 hours before assay, followed by counting incorporated ${ }^{3} \mathrm{H}$-thymidine into the cells with a Packard matrix 9600 beta-counter apparatus.

\section{Mitogen Induced Lymphocyte Blastogenesis}

Lymphocyte blastogenesis was examined by the method described previously [6]. Murine spleen cells $\left(1 \times 10^{6} / \mathrm{ml}\right)$ were cultured for 72 hours with Con A $(0.5 \mu \mathrm{g} / \mathrm{ml})$ or LPS $(2.0 \mu \mathrm{g} / \mathrm{ml})$ in the various concentrations of kigamicin D. Antiproliferation activities were examined by measuring the incorporation of ${ }^{3} \mathrm{H}$-thymidine as in the case of MLCR.

\section{Graft Versus Host Reaction (GvHR)}

GvHR was induced by the method of Ford et al. [7]. Spleen cells used as the graft were taken from adult C57BL/6 mice and injected into the right footpad of 7-day-old $\mathrm{BDF}_{1}$ mice in an inoculum form of $10^{7}$ cells $/ 50 \mu$ l. Kigamicin D was orally administered once daily for 5 days from the next day after inoculation of the allogenic spleen cells. As a positive control, 15-deoxyspergualin (DSG, saline solution) was intraperitoneally administered according to the same schedule as kigamicin D. Seven days later, the mice were sacrificed and popliteal lymph nodes were removed from both extremities. Lymph node weights were measured. Enlargement in lymph nodes was calculated as a difference between the popliteal lymph node weight of right (injected) leg and that of left (uninjected) leg.

\section{NK Cells Activity}

Spleen cells from $\mathrm{BDF}_{1}$ mice that had received daily oral administration of kigamicin $\mathrm{D}$ and cytostatin (CTS) for 3 days, were prepared and NK cells activity was examined. CTS $(2.5 \mathrm{mg} / \mathrm{kg})$ was administered intraperitoneally as a positive control. One day after the last treatment, spleen cells were prepared. NK cytolytic activity was performed by a modification of calcein-AM assay as previously described in detail [8]. Briefly, spleen cells obtained from mice were used as effector cells. YAC-1 cells labeled with $10 \mu \mathrm{g} / \mathrm{ml}$ of calcein-AM were used as target cells. Labeled YAC- 1 cells $\left(0.1 \mathrm{ml}, 2 \times 10^{4}\right.$ cells $)$ and effector cells $(0.1 \mathrm{ml})$ were added to each well of a 96-well plate to produce various effector-to-target $(\mathrm{E} / \mathrm{T})$ ratios. This plate was incubated for 4 hours at $37^{\circ} \mathrm{C}$. Fluorescence of cell-free supernatant $(0.1 \mathrm{ml}$ from each well $)$ after centrifugation was measured via a spectrofluorometer (Labsystems Fluoroscan II; Dainippon Seiyaku, Osaka, Japan), using an excitation of $475 \mathrm{~nm}$ and an emission of $538 \mathrm{~nm}$. Cytolytic activity (as \% lysis) was calculated by the following formula: \% of specific lysis $=(E-S)$ / $(M-S) \times 100$ (where $E$ is fluorescence in experimental cultures; $S$ is the spontaneous fluorescence released in cultures containing target cells alone; $M$ is the maximum fluorescence obtained by lysing all cells with $0.5 \%$ Triton X-100.

\section{Delayed-type Hypersensitivity (DTH)}

DTH to sheep red blood cells (SRBC) was performed according to the method described previously [9]. Female 13-weeks-old $\mathrm{CDF}_{1}$ mice were immunized by intravenous injection of $10^{5}$ SRBC $(0.1 \mathrm{ml}$, saline). Kigamicin D and bestatin (saline solution) as a positive control, were orally administered daily for 4 days starting from the day of immunization. An immunosuppressant, DSG (saline solution) was intraperitoneally administered according to the same schedule as kigamicin D. Four days after immunization, DTH response was elicited by subcutaneous injection of $10^{8} \mathrm{SRBC}(50 \mu \mathrm{l}$, saline) to the footpad, and 24 hours later, the footpad thickness was measured with a caliper. Footpad swelling was obtained by subtracting mean footpad thickness of normal mice from those of each DTH group $(\mathrm{n}=5)$.

\section{Statistical Analysis}

All results were expressed as means \pm S.D. Statistical comparisons were made using Student's $t$ test after analysis of variance. The results were considered to be significantly different if $P$ value $<0.05$.

\section{Results and Discussion}

\section{MLCR}

As shown in Table 1, kigamicin D did not inhibit MLCR, but $0.049 \mu \mathrm{g} / \mathrm{ml}$ showed statistically significant $(p<0.01)$ elevation of MLCR to control (168\%). Higher concentration above $0.195 \mu \mathrm{g} / \mathrm{ml}$ showed cytotoxicity.

\section{Mitogen Induced Lymphocyte Blastogenesis}

As shown in Table 2, kigamicin D did not show mitogenic activity on spleen cells by itself. It did not show any effect on Con A or LPS induced blastogenesis unlike PMA. 


\section{GvHR}

As shown in Table 3, kigamicin D did not show any effect on GvHR.

Table 1 Effect of kigamicin D on MLCR

\begin{tabular}{rcc}
\hline & cpm \pm S.D. ${ }^{*}$ & T/C (\%) \\
\hline $\begin{array}{l}\text { Responder cells alone } \\
\text { MLCR }\end{array}$ & $79 \pm 9$ & \\
Kigamicin D $(\mu \mathrm{g} / \mathrm{ml})$ & $2588 \pm 131$ & 100 \\
0.003 & $2290 \pm 525$ & \\
0.012 & $2809 \pm 410$ & 109 \\
0.049 & $4337 \pm 561$ & 168 \\
0.195 & $3 \pm 1$ & 0.1 \\
0.781 & $4 \pm 1$ & 0.2 \\
\hline
\end{tabular}

* ${ }^{3} \mathrm{H}$-thymidine incorporation into the cells were counted.

\section{NK Cells Activity}

NK cells play an important role in immune surveillance against tumor development. Effect on NK cells activity was evaluated by a modified calcein-AM assay. As shown in Fig. 1, spleen cells from mice administered orally by kigamicin D showed the same NK activity as spleen cells from non-treated mice, while CTS [10] treated as a positive control, significantly augmented NK activity.

\section{DTH}

The results above mentioned show kigamicin $\mathrm{D}$ has no mitogenic activity such as bestatin and swainsonine, and immunosuppressive activity such as DSG. Kigamicin D does not have direct effect on T, B, and NK lymphocytes. From our observation that the site of administration in the case of intravenous treatment became hardened and swollen, we examined effect of kigamicin D on antigen specific immune response. As shown in Fig. 2, oral

Table 2 Effect of kigamicin D on mitogens induced blastogenesis

\begin{tabular}{|c|c|c|c|c|c|c|}
\hline \multirow{3}{*}{$\begin{array}{l}\text { Kigamicin D } \\
\qquad(\mu \mathrm{g} / \mathrm{ml})\end{array}$} & \multicolumn{6}{|c|}{ Mitogen } \\
\hline & \multicolumn{2}{|c|}{ None } & \multicolumn{2}{|c|}{ Con A } & \multicolumn{2}{|c|}{ LPS } \\
\hline & cpm \pm S.D. $*$ & $\mathrm{~T} / \mathrm{C}(\%)$ & cpm \pm S.D. $*$ & $\mathrm{~T} / \mathrm{C}(\%)$ & cpm \pm S.D. $*$ & $\mathrm{~T} / \mathrm{C}(\%)$ \\
\hline 0 & $731 \pm 92$ & 100 & $3546 \pm 117$ & 100 & $1548 \pm 137$ & 100 \\
\hline 0.001 & $910 \pm 90$ & 124 & $3592 \pm 293$ & 101 & $1432 \pm 68$ & 93 \\
\hline 0.004 & $757 \pm 109$ & 104 & $3333 \pm 273$ & 94 & $1450 \pm 128$ & 94 \\
\hline 0.016 & $615 \pm 120$ & 84 & $3427 \pm 479$ & 97 & $1462 \pm 78$ & 94 \\
\hline 0.063 & $70 \pm 41$ & 10 & $2115 \pm 515$ & 60 & $1668 \pm 127$ & 108 \\
\hline 0.25 & $3 \pm 2$ & 0.4 & $8 \pm 2$ & 0.2 & $7 \pm 1$ & 0.5 \\
\hline 1 & $6 \pm 4$ & 0.8 & $10 \pm 2$ & 0.3 & $10 \pm 2$ & 0.6 \\
\hline
\end{tabular}

${ }^{*} \mathrm{H}$-thymidine incorporation into the cells were counted.

Table 3 Effect of kigamicin D on GvHR

\begin{tabular}{|c|c|c|c|}
\hline & $\begin{array}{l}\text { Enlargement of lymph node }(\mathrm{mg}) \\
\text { Mean } \pm \text { S.D. }\end{array}$ & $\begin{array}{l}\text { Inhibition } \\
\%\end{array}$ & $P$ \\
\hline Control (none) & $8.72 \pm 1.26$ & & \\
\hline \multicolumn{4}{|l|}{ Kigamicin D (mg/kg) } \\
\hline 0.19 & $10.45 \pm 1.47$ & -19.9 & n.s \\
\hline 0.75 & $10.50 \pm 1.39$ & -20.4 & n.s \\
\hline 3 & $9.76 \pm 1.56$ & -11.9 & n.s \\
\hline 12 & $11.13 \pm 2.37$ & -27.6 & n.s \\
\hline 24 & $7.34 \pm 1.59$ & 15.8 & n.s \\
\hline \multicolumn{4}{|l|}{ DSG $(\mathrm{mg} / \mathrm{kg})$} \\
\hline 25 & $3.14 \pm 0.91$ & 64 & $<0.001$ \\
\hline
\end{tabular}




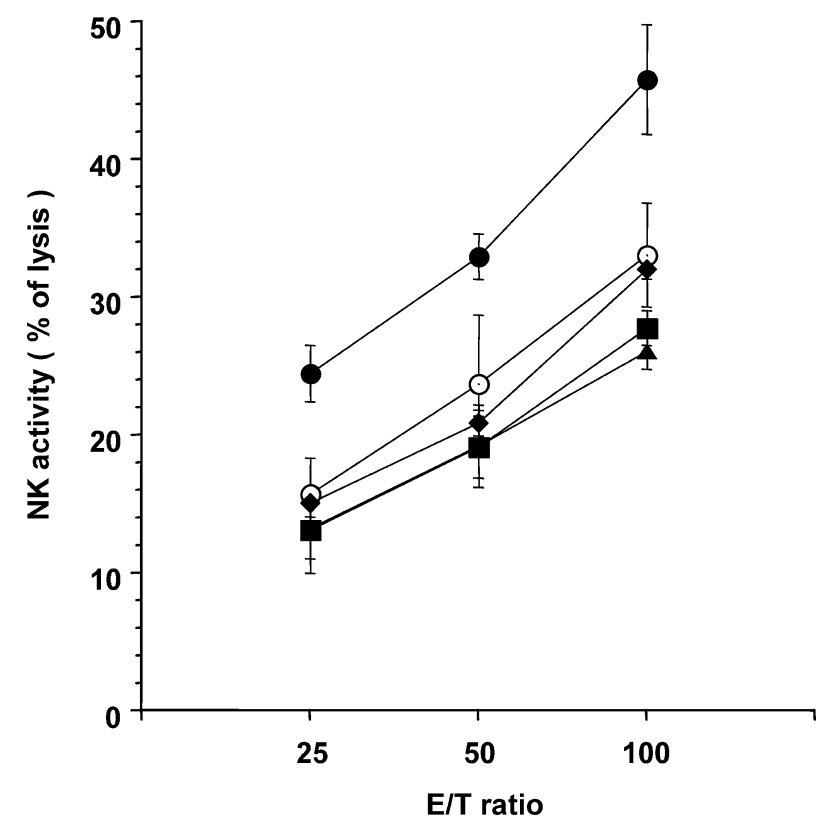

Fig. 1 Effect of kigamicin D orally administered on NK activity.

o, Control (none); •, CTS $2.5 \mathrm{mg} / \mathrm{kg} ; \boldsymbol{\Delta}$, kigamicin D $3.0 \mathrm{mg} / \mathrm{kg}$; 匹, kigamicin D $0.75 \mathrm{mg} / \mathrm{kg} ; \bullet$, kigamicin D $0.19 \mathrm{mg} / \mathrm{kg}$.

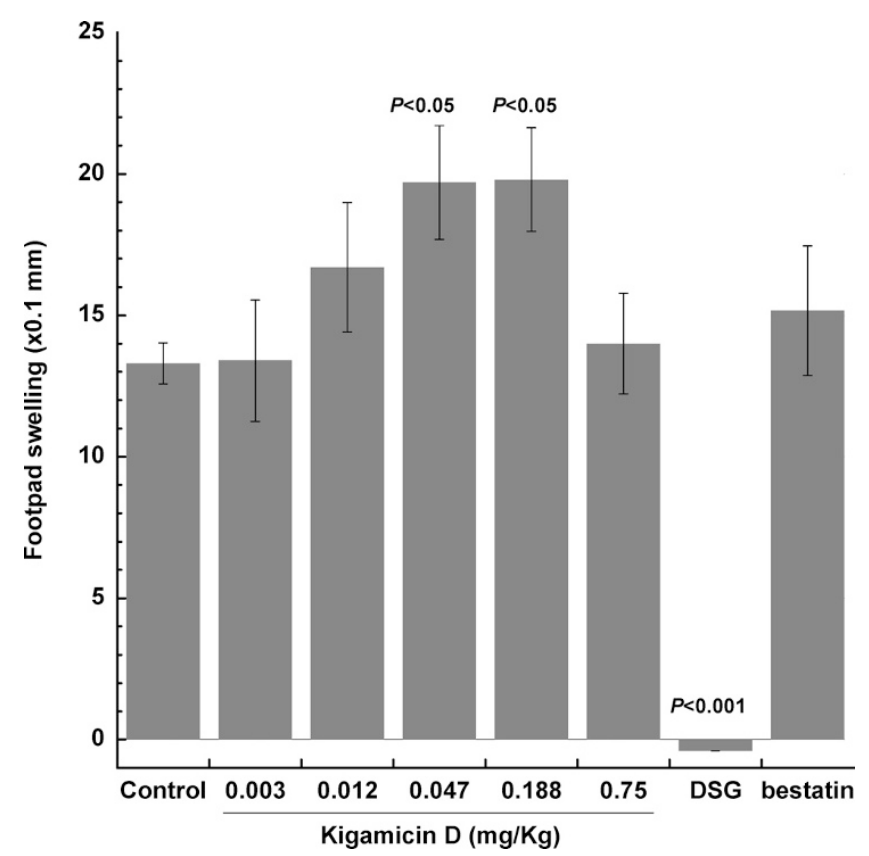

Fig. 2 Effect of kigamicin D on DTH.

administration of kigamicin D augmented DTH response at doses from 0.012 to $0.188 \mathrm{mg} / \mathrm{kg}$. The activity was beyond bestatin.

As described elsewhere, we determined that interferon $\gamma$ and TNF- $\alpha$ were highly induced in spleen cells from mice administered oral kigamicin $\mathrm{D}$, and IL-12 production in dendritic cells was induced by kigamicin $\mathrm{D}$ in vitro. The augmentation of the cellular immunity was suggested to be caused by activation of dendritic cells (DCs) by kigamicin D.

Moreover, kigamicin D increased IL-6 production induced by LPS in P388D1 cells, a macrophage cell line in vitro (to be published elsewhere). Thus the target cells of kigamicin D in immune response seemed to be antigen presenting cells such as DCs and macrophages.

The signal transduction mechanism of how kigamicin D shows effect on antigen presenting cells may be related to inhibition of PI3K/Akt pathway by kigamicin D under nutrient deprived condition. Fukuo T. and Koyasu S. [11] have shown that PI3K is an endogenous suppressor of IL-12 production and Th1 dominant immune response, in studies of the immune response of $\mathrm{p} 85 \alpha$ regulatory subunit of class IA PI3K knockout mice and IL-12 production from DCs in vitro by wortmannin, a PI3K inhibitor. Kigamicin D inhibits PI3K/Akt pathway as previously described [2] and PI3K inhibitors such as wortmannin and LY294002 showed the same activity inhibiting cancer cell viability preferentially during nutrient starvation like kigamicin D $[2,12]$. Kigamicin D showed antiangiogenic activity [4] like PI3K inhibitors and induced IL-12 production from DCs in vitro as described elsewhere.

DCs, powerful antigen presenting cells capable of inducing primary $\mathrm{T}$ cell responses in vitro and in vivo has recently generated widespread interest in DC-based immunotherapy of several human malignancies. Kigamicin D which acts on DCs may be useful for eliciting stronger antigen recognition and cytotoxic $\mathrm{T}$ cells response.

Acknowledgment This work was supported by Grants-in-Aid for Research on Cancer from the Ministry of Education, Culture, Sports, Science and Technology of Japan and for the Third-Term Comprehensive 10-Year Strategy for Cancer Control from the Ministry of Health, Labor, and Welfare of Japan.

\section{References}

1. Kunimoto S, Lu J, Esumi H, Yamazaki Y, Kinoshita N, Honma Y, Hamada M, Ohsono M, Ishizuka M, Takeuchi T. Kigamicins, novel antitumor antibiotics. I. Taxonomy, isolation, physico-chemical properties and biological activities. J Antibiot 56: 1004-1011 (2003)

2. Lu J, Kunimoto S, Yamazaki Y, Kaminishi M, Esumi H. Kigamicin D, a novel anticancer agent based on a new antiausterity strategy targeting cancer cells' tolerance to nutrient starvation. Cancer Sci 95: 547-552 (2004) 
3. Ishizuka M, Masuda T, Kanbayashi N, Fukasawa S, Takeuchi T, Aoyagi T, Umezawa H. Effect of bestatin on mouse immune system and experimental murine tumors. J Antibiot 33: 642-652 (1980)

4. Masuda T, Ohba S, Kawada M, Osono M, Ikeda D, Esumi $\mathrm{H}$, Kunimoto S. Antitumor effect of kigamicin D on mouse tumor models. J Antibiot 59: 209-214 (2006)

5. Ishizuka M, Masuda T, Mizutani S, Osono M, Kumagai H, Takeuchi T, Umezawa H. Induction of antitumor resistance to mouse leukemia L1210 by spergualins. J Antibiot 32: 1736-1743 (1986)

6. Ishizuka M, Sato J, Sugiyama Y, Takeuchi T, Umezawa H. Mitogenic effect of bestatin on lymphocytes. J Antibiot 33: 653-662 (1980)

7. Ford WL. Measurement of graft versus-host activity. In Handbook of Experimental Immunology. Ed., Weilerz DM, pp. 30.1-30.12, Blackwell scientific publication, Oxford (1978)

8. Ayalon O, Hughes EA, Creswell P, Lee J, O’Donnell L,
Pardi R, Bender JR. Induction of transporter associated with antigen processing by interferon gamma confers endothelial cell cytoprotection against natural killer-mediated lysis. Proc Natl Acad Sci USA 95: 2435-2440 (1998)

9. Masuda T, Mizutani S, Iijima M, Odai H, Suda H, Ishizuka M, Takeuchi T, Umezawa H. Immunosuppressive activity of 15-deoxyspergualin and its effect on skin allografts in rats. J Antibiot 40: 1612-1618 (1987)

10. Kawada M, Kawatsu M, Masuda T, Ohba S, Amemiya M, Kohama T, Ishizuka M, Takeuchi T. Specific inhibitors of protein phosphatase $2 \mathrm{~A}$ inhibit tumor metastasis through augmentation of natural killer cells. Int Immunopharmacol 3: 179-188 (2003)

11. Fukao T, Koyasu S. PI3K and negative regulation of TLR signaling. Trends in Immunol 24: 358-363 (2003)

12. Masuda T, Ikeda D, Esumi H, Kunimoto S. Selective cytotoxicity of kigamicin D to PANC-1 cells under nutrient deprived medium in vitro. J Antibiot 59: $\mathrm{xxx}-\mathrm{xxx}$ (2006) 